\title{
Low prevalence of antibodies against Toxoplasma gondii in dairy cattle from China's central region
}

\author{
Hui Dong ${ }^{1 \dagger}$, Yao Yao Lu $^{1 \dagger}$, Rui Jing Su', Ying Hua Wang ${ }^{2}$, Meng Yao Wang ${ }^{1}$, Yi Bao Jiang ${ }^{1}$ and Yu Rong Yang ${ }^{1 *}$ (D)
}

\begin{abstract}
Background: Toxoplasma gondii is an intracellular protozoan that can infect humans and other animals, including cattle. Cattle are one of the world's main sources of meat, and people who consume raw or undercooked meat and milk of cattle infected with T. gondii can become infected. In this study, a total of 5292 dairy cattle serum samples, collected from 17 cities (Henan Province, China) from January 2015 to September 2017, were screened for antibodies against T. gondii.

Results: Antibodies to T. gondii were found in 1.93\% (102/5292) (95\% Cl, 1.56-2.30) of dairy cattle using a modified agglutination test (cut-off 1:100). The results showed that geographic location and season may be risk factors for $T$. gondii infection of cattle $(P<0.05)$, and the seroprevalence of $T$. gondii in cattle along the Yellow River is higher than other areas.

Conclusions: This is the first large-scale investigation on the seroprevalence of T. gondii infection in cattle from Central China. This survey shows that the T. gondii infection rate of dairy cattle is low; however, these findings provide additional information on the epidemiology of Chinese T. gondii. The possibility of dairy cattle exposure to $T$. gondii in Central China can not be ignored, and the consumption of raw or undercooked beef or milk may pose a risk to human health.
\end{abstract}

Keywords: Toxoplasma gondii, Cattle, Seroprevalence, Modified agglutination test, Risk factor, Henan Province, China

\section{Background}

Toxoplasma gondii is an intracellular protozoan parasite that can infect a wide variety of host species, including cattle [1]. The seroprevalence of $T$. gondii infection varies among host species. Although cattle appear to be poor hosts for T. gondii, T. gondii can still infect cattle and viable $T$. gondii strain had been isolated from the intestines of naturally infected cows [2,3]. Cattle infected with $T$. gondii pose a risk for toxoplasmosis in people who consume raw or undercooked meat and unpasteurized milk [4]. In humans, $T$. gondii can cause encephalitis, retinitis, newborn hydrocephalus $[1,5]$, and even death [6].

Approximately 211 million cattle are raised in China, accounting for $14.4 \%$ of the world's cattle population (National Bureau of Statistics of China, 2015 update).

\footnotetext{
* Correspondence: yangyu7712@sina.com

${ }^{+}$Hui Dong and Yao Yao Lu contributed equally to this work.

${ }^{1}$ College of Animal Science and Veterinary Medicine, Henan Agricultural

University, Zhengzhou, People's Republic of China

Full list of author information is available at the end of the article
}

Surveys regarding $T$. gondii infection in cattle have been reported in some parts of China. However, only three reports on cattle $T$. gondii infections in the central region of China have been published to date, which indicated that the prevalence of T. gondii was $20.10 \%$ (79/393) in 2011-2013 by IHA (95\% CI 16.14-24.06) [7], $5.38 \%(43 / 800)$ in $2011-2012$ by IgG test paper (95\% CI 3.81-6.94) [8], and $0(0 / 102)$ in $2013-2014$ by IHA [9], and there requires more reports as a support to summarize and analyze the epidemiological situation in the region. Large quantities of milk and meat are consumed each year in China, and the safety of the cattle products with respect to $T$. gondii infection is unknown. The objective of this investigation was to estimate the seroprevalence and risk of T. gondii infection in dairy cattle from Central China. To our knowledge, the present study is the most extensive investigation of $T$. gondii infections in dairy cattle from Central China.

(C) The Author(s). 2018 Open Access This article is distributed under the terms of the Creative Commons Attribution 4.0 International License (http://creativecommons.org/licenses/by/4.0/), which permits unrestricted use, distribution, and 


\section{Methods}

\section{Investigation site and serum samples}

Henan Province is located in the central region of China. Henan Province (latitude $34.90^{\circ} \mathrm{N}$, longitude $113.50^{\circ} \mathrm{E}$ ) has a humid and subtropical climate. From east to west, the plains transition into the hilly mountains. The average annual temperature is $15.7{ }^{\circ} \mathrm{C}$ to $12.1{ }^{\circ} \mathrm{C}$, and the average annual precipitation is 1380.6 to $532.5 \mathrm{~mm}$. The sera of 5292 dairy cattle from 49 farms in 17 cities were collected by local veterinarians from January 2015 to September 2017 (Table 1, Fig. 1). Cattle feed consists of silage, hay, and fresh grass. The cattle were females, and their ages ranged from 2 to 15 years. The farm names and sample collection dates were recorded. The sera were used for Brucellosis screening, which in turn also allowed us to survey for T. gondii infection. The cattle sera were separated from jugular vein blood and transported to the Laboratory of Veterinary Pathology, Henan Agricultural University (Zhengzhou, Henan, China) in cooler boxes. The samples were stored at $4{ }^{\circ} \mathrm{C}$ and tested for $T$. gondii antibodies within one week.

\section{Assessment for T. gondii antibodies}

The serum samples were tested for antibodies against $T$. gondii by modified agglutination test (MAT) [10]. Sera with MAT titers of 1:100 or higher were considered positive for T. gondii [1]. Whole formalin-treated T. gondii tachyzoite antigens were obtained from the University of Tennessee Research Foundation (Knoxville, TN, USA; https://utrf.tennessee.edu/). T. gondii-positive mouse sera were provided by Dr. J. P. Dubey (Beltsville, ARS, USDA) as reference sera. All serum samples were tested at $1: 100$, then the dilution was doubled to the maximum titer, and positive controls and negative controls were run on each plate.

\section{Statistical analysis}

Statistical analysis was performed using GraphPad Prism 4.0 software (GraphPad Software Inc., San Diego, CA, USA). The data were analyzed using the chi-square test or Fisher's exact test to assess the association between seropositivity and risk factors based on region (17 cities), season (spring, summer, autumn, and winter), and geographic location (north of the Yellow River, south of the Yellow River).

\section{Results}

Our survey indicated that 1.93\% (102/,5292) (95\% CI, 1.56-2.30) of the examined dairy cattle were seropositive for T. gondii infection by MAT, with titers of 1:100 in 102 cattle, $1: 200$ in $40,1: 400$ in $21,1: 800$ in $17,1: 1600$ in 12, and 1:3200 in 7 (Table 1). The seroprevalence of T. gondii infection in cattle from 17 cities ranged from 0 to $10 \%$. No information on the geographical locations from 756 cattle samples was available. The seroprevalence rates of $T$. gondii varied with regions. The differences in T. gondii seroprevalence among different regions are shown in Table 2. A high prevalence was observed in LuoYang and ZhouKou compared to the other regions $(P<0.05)$, and no seropositive sera from cattle were observed in SanMenXia and XinYang.

Risk factors in relation to geographic location and season were analyzed. The prevalence of $T$. gondii in dairy cattle along the Yellow River was higher than in the other areas (Fig. 1). The seroprevalence of $T$. gondii in cattle from south of the Yellow River (3.67\%, 57/2116) was higher than that in the north of the Yellow River (1.69\%, 41/2420), with a statistically significant odds ratio of 1.606 (95\% CI, 1.0712.410) $(P=0.027)$. In the summer, no positive sera for $T$. gondii were detected in dairy cattle by MAT $(n=416)$. In spring, $T$. gondii antibodies were identified in $3(0.71 \%)$ of 424 samples. In winter, 14 (1.52\%) of 921 serum samples tested positive for $T$. gondii antibodies. Out of the 3531 samples collected in autumn, 85 (2.41\%) samples were determined to be positive. Seroprevalence was higher in the autumn in contrast to the spring and winter, and the difference between autumn and spring was statistically significant (OR 3.462; $P=0.039$ ) (Table 3).

\section{Discussion}

It has been estimated that about one third of the world population has been infected with $T$. gondii $[5,11]$. Infection is often most common in areas that have hot, humid climates and lower altitudes [1]. Cattle can be readily infected with $T$. gondii, but they are considered poor hosts because these have developed a more effective immune response to $T$. gondii infection than sheep that possibly facilitates in $T$. gondii elimination from tissues, as well as transient antibody responses [12-14]. However, $T$. gondii has been isolated from cattle tissues or unpasteurized milk [13], indicating that meat and milk may be sources of $T$. gondii infections. T. gondii has also been detected in cattle semen [1], suggesting it may be transmitted by venereal contact or artificial insemination.

Several test methods have been used in the diagnosis of T. gondii infection in humans. However, these could not be applied to cattle based on its incompatibility with the bovine immunoglobulin G system [15]. Current understanding of the specificity and sensitivity of serological diagnosis of $T$. gondii infection in cattle is limited. Furthermore, cattle may not readily acquire persistent $T$. gondii infections, and the actual prevalence rates based on serum antibodies to $T$. gondii are difficult to ascertain. Previous reports have screened for $T$. gondii antibodies in cattle sera at a 1:100 dilution or higher by MAT $[1,16]$, prompting us to use this as a cut-off in the present study. 
Table 1 Seroprevalence of T. gondii in cattle in Henan Province

\begin{tabular}{|c|c|c|c|c|c|c|c|c|c|c|}
\hline \multirow[t]{2}{*}{ Location/ City } & \multirow{2}{*}{$\begin{array}{l}\text { Samples obtained } \\
\text { date }\end{array}$} & \multirow{2}{*}{$\begin{array}{l}\text { Tested } \\
\text { No. }\end{array}$} & \multicolumn{6}{|c|}{ No. of seropositive samples /(titer) } & \multirow{2}{*}{$\begin{array}{l}\% \text { (Positive No. } \\
\text { /Test No.) }\end{array}$} & \multirow[t]{2}{*}{$95 \% \mathrm{Cl}$} \\
\hline & & & $1: 100$ & $1: 200$ & $1: 400$ & 1:800 & $1: 1600$ & $1: 3200$ & & \\
\hline \multirow[t]{3}{*}{ I ZhengZhou } & $24 \operatorname{Sep} 2015^{b}$ & 209 & 2 & - & - & - & - & - & $0.54 \%(2 / 369)$ & $0.02-2.09$ \\
\hline & 21 Apr 2017 & 30 & - & - & - & - & - & - & & \\
\hline & 01 Aug 2017 & 130 & - & - & - & - & - & - & & \\
\hline \multirow[t]{2}{*}{ II KaiFeng } & 19 Oct 2015 & 42 & 3 & - & - & - & - & - & $3.49 \%(3 / 86)$ & $0.77-10.18$ \\
\hline & 24 Sep 2015 & 44 & - & - & - & - & - & - & & \\
\hline \multirow[t]{3}{*}{ III PingDingShan } & 25 Sep 2015 & 300 & 7 & 3 & 2 & 2 & 1 & - & $1.98 \%(7 / 353)$ & $0.88-4.12$ \\
\hline & 27 Jun 2017 & 4 & - & - & - & - & - & - & & \\
\hline & 07 Jun 2017 & 49 & - & - & - & - & - & - & & \\
\hline \multirow[t]{2}{*}{ IV LuoYang } & 22 Sep 2015 & 280 & 31 & 23 & 12 & 9 & 6 & 6 & $10.00 \%(31 / 310)$ & $7.10-13.88$ \\
\hline & 22 Mar 2017 & 30 & - & - & - & - & - & - & & \\
\hline \multirow[t]{6}{*}{ V AnYang } & 15 Jan 2015 & 369 & 2 & - & - & - & - & - & $0.41 \%(2 / 488)$ & $0.01-1.58$ \\
\hline & 05 Jul 2016 & 4 & - & - & - & - & - & - & & \\
\hline & 25 Apr 2017 & 32 & - & - & - & - & - & - & & \\
\hline & 07 Jun 2017 & 31 & - & - & - & - & - & - & & \\
\hline & 28 Jun 2017 & 22 & - & - & - & - & - & - & & \\
\hline & 29 Jun 2017 & 30 & - & - & - & - & - & - & & \\
\hline \multirow[t]{4}{*}{ Vl JiaoZuo } & 16 Oct 2015 & 200 & 7 & - & - & - & - & - & $2.29 \%(7 / 306)$ & $1.02-4.74$ \\
\hline & 22 Apr 2017 & 29 & - & - & - & - & - & - & & \\
\hline & 26 Jun 2017 & 29 & - & - & - & - & - & - & & \\
\hline & 05 Sep 2017 & 48 & - & - & - & - & - & - & & \\
\hline \multirow[t]{2}{*}{ VII HeBi } & 15 Jan 2015 & 552 & 12 & 2 & 2 & 2 & 2 & - & $2.07 \%(12 / 581)$ & $1.14-3.62$ \\
\hline & 15 Jun 2017 & 29 & - & - & - & - & - & - & & \\
\hline \multirow[t]{2}{*}{ VII XinXiang } & 16 Oct 2015 & 452 & 11 & 2 & 1 & 1 & - & - & $2.28 \%(11 / 482)$ & $1.23-4.09$ \\
\hline & 22 Mar 2017 & 30 & - & - & - & - & - & - & & \\
\hline \multirow[t]{2}{*}{ IX PuYang } & 15 Oct 2015 & 250 & 2 & - & - & - & - & - & $0.71 \%(2 / 283)$ & $0.02-2.71$ \\
\hline & 05 Sep 2017 & 33 & - & - & - & - & - & - & & \\
\hline \multirow[t]{3}{*}{ X XuChang } & 25 Sep 2015 & 200 & 5 & 2 & 2 & 2 & 2 & - & $1.77 \%(5 / 282)$ & $0.64-4.20$ \\
\hline & 26 Apr 2017 & 52 & - & - & - & - & - & - & & \\
\hline & 27 Apr 2017 & 30 & - & - & - & - & - & - & & \\
\hline XI LuoHe & 25 Sep 2015 & 50 & 1 & - & - & - & - & - & $2.00 \%(1 / 50)$ & $0.01-11.47$ \\
\hline \multirow[t]{3}{*}{ XII SanMenXia } & 23 Sep 2015 & 81 & - & - & - & - & - & - & $0(0 / 150)$ & - \\
\hline & 21 Apr 2017 & 23 & - & - & - & - & - & - & & \\
\hline & 07 Sep 2017 & 46 & - & - & - & - & - & - & & \\
\hline \multirow[t]{5}{*}{ XIII NanYang } & 14 Oct 2015 & 170 & 2 & - & - & - & - & - & $1.06 \%(3 / 283)$ & $0.21-3.22$ \\
\hline & 21 Mar 2017 & 16 & - & - & - & - & - & - & & \\
\hline & 22 Mar 2017 & 39 & - & - & - & - & - & - & & \\
\hline & 27 Jun 2017 & 29 & - & - & - & - & - & - & & \\
\hline & 07 Sep 2017 & 29 & 1 & - & - & - & - & - & & \\
\hline XIV XinYang & 18 Apr 2017 & 31 & - & - & - & - & - & - & $0(0 / 31)$ & - \\
\hline \multirow[t]{2}{*}{ XV Zhoukou } & 19 Oct 2015 & 50 & 2 & 1 & - & - & - & - & $5.63 \%(4 / 71)$ & $1.80-14.03$ \\
\hline & 21 Mar 2017 & 21 & 2 & 2 & 2 & 1 & 1 & 1 & & \\
\hline XVI ZhuMaDian & 25 Apr 2017 & 31 & - & - & - & - & - & - & $0.76 \%(1 / 131)$ & $0.01-4.62$ \\
\hline
\end{tabular}


Table 1 Seroprevalence of T. gondii in cattle in Henan Province (Continued)

\begin{tabular}{|c|c|c|c|c|c|c|c|c|c|c|}
\hline \multirow[t]{2}{*}{ Location/ City } & \multirow{2}{*}{$\begin{array}{l}\text { Samples obtained } \\
\text { date }\end{array}$} & \multirow{2}{*}{$\begin{array}{l}\text { Tested } \\
\text { No. }\end{array}$} & \multicolumn{6}{|c|}{ No. of seropositive samples /(titer) } & \multirow{2}{*}{$\begin{array}{l}\text { \% (Positive No. } \\
\text { /Test No.) }\end{array}$} & \multirow[t]{2}{*}{$95 \% \mathrm{Cl}$} \\
\hline & & & $1: 100$ & $1: 200$ & $1: 400$ & $1: 800$ & $1: 1600$ & $1: 3200$ & & \\
\hline & 06 Sep 2017 & 90 & 1 & - & - & - & - & - & & \\
\hline \multirow[t]{2}{*}{ XVII JiYuan } & 24 Sep 2015 & 250 & 6 & 1 & - & - & - & - & $2.50 \%(7 / 280)$ & $1.11-5.17$ \\
\hline & 22 Mar 2017 & 30 & 1 & 1 & - & - & - & - & & \\
\hline \multirow[t]{3}{*}{$X V I I N K^{a}$} & 14 Oct 2015 & 657 & 4 & 3 & - & - & - & - & $0.53 \%(4 / 756)$ & $0.15-1.40$ \\
\hline & 16 Oct 2015 & 50 & - & - & - & - & - & - & & \\
\hline & 04 Jul 2017 & 49 & - & - & - & - & - & - & & \\
\hline Total & & 5292 & 102 & 40 & 21 & 17 & 12 & 7 & $1.93 \%(102 / 5292)$ & $1.59-2.34$ \\
\hline
\end{tabular}

${ }^{\mathrm{a}} \mathrm{NK}$ means the city information of samples were not known

${ }^{\mathrm{b}}$ The samples sampled on same date from a single farm

Dubey and Jokelainen et al. have conducted T. gondii serological testing of cattle [13, 17], and emphasize that the results of $T$. gondii serological screening of cattle should be interpreted with caution. Serology is an indirect method, and the positive results indicate that the host has been exposed to the parasite and produced measurable humoral immune responses. An increase in seroprevalence in cattle up to the age of five years has been reported
[17]. The details of the age of the cattle included in the current study were unfortunately unknown, but the age range was wide and did not include only old cattle.

The overall estimated global prevalence of $T$. gondii in cattle using various detection methods is $14.96 \%$ (8286/ $55,377,1.40-91.80 \%$ ) [1]. Furthermore, the overall estimated seroprevalence of $T$. gondii in other larger ruminants, specifically water buffalo, horse, and camel was

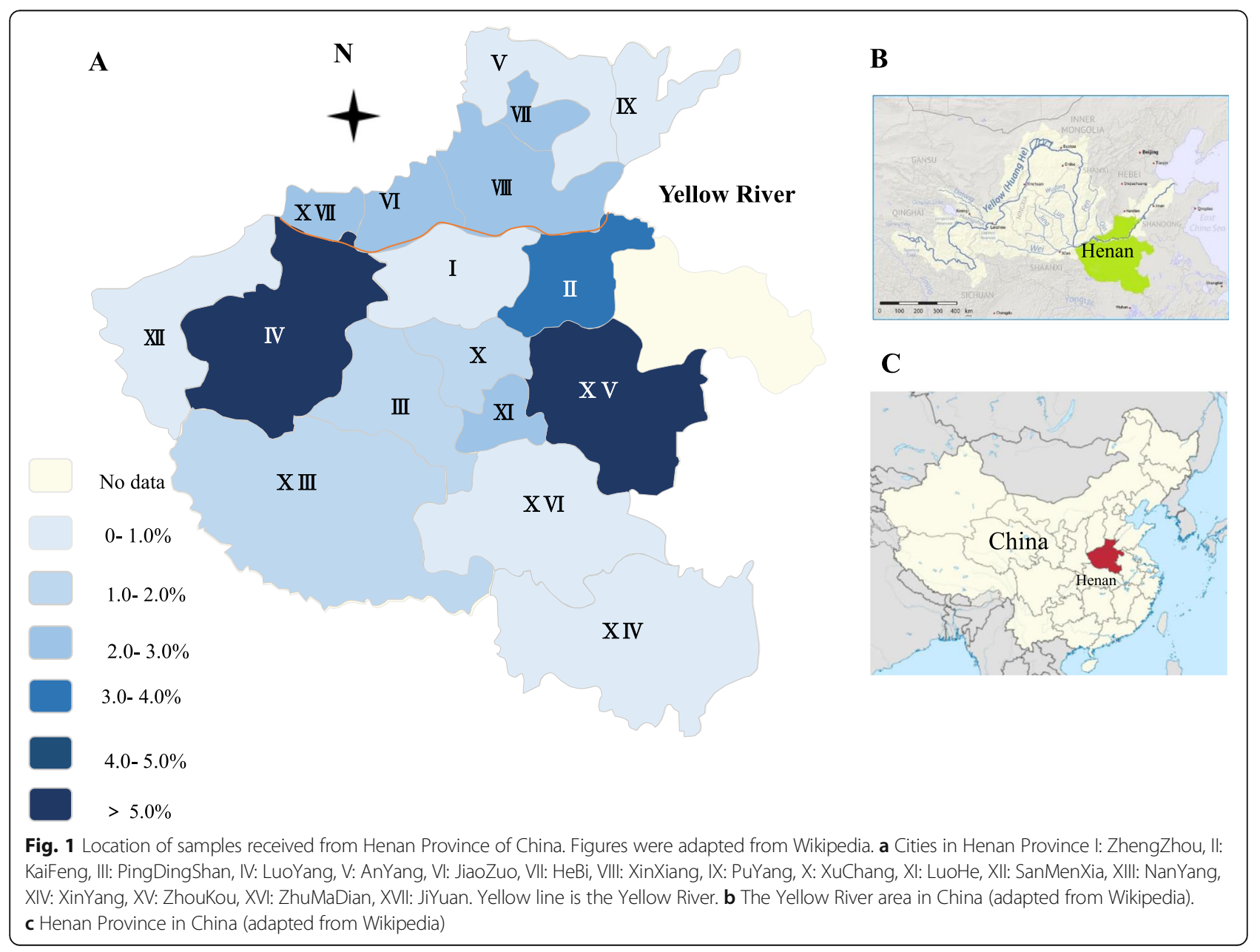




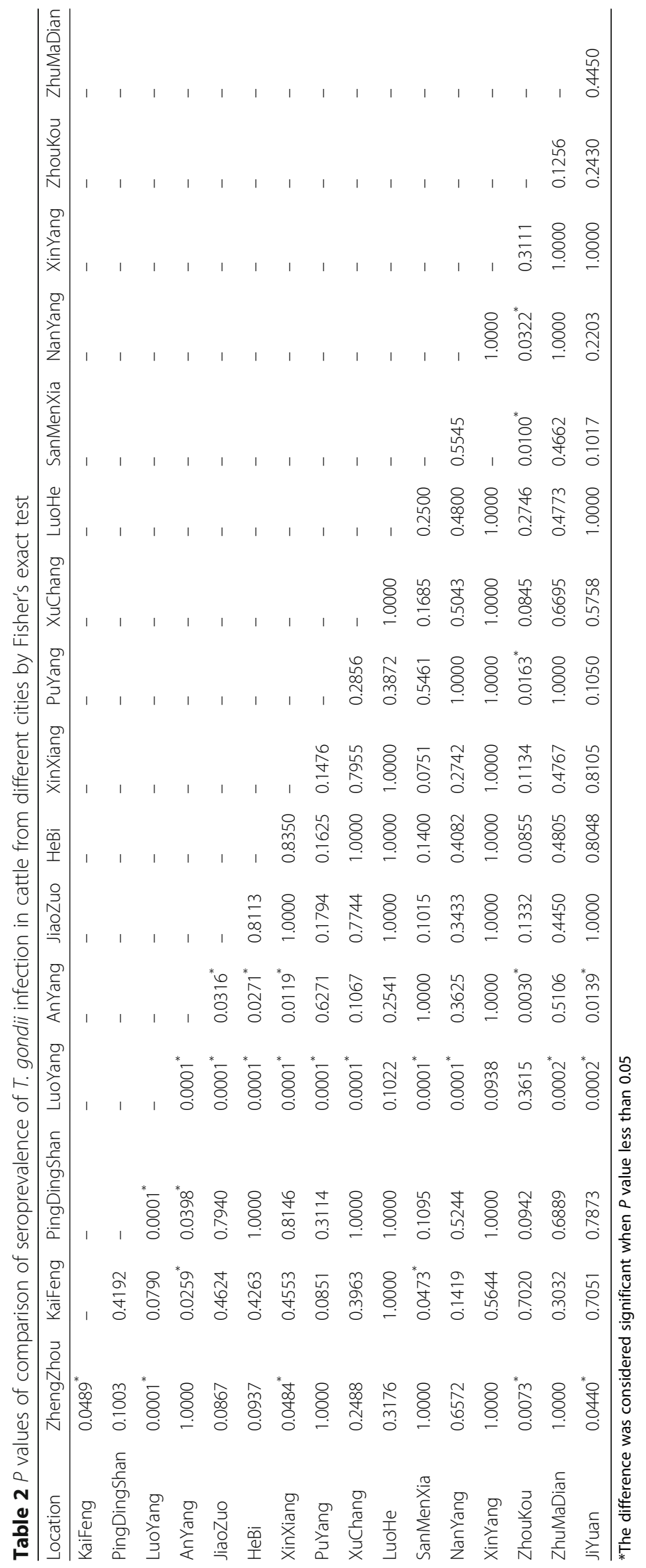


Table 3 Seroprevalence and risk factors of T. gondii in dairy cattle in Henan Province

\begin{tabular}{|c|c|c|c|c|c|c|c|c|c|c|}
\hline \multirow[t]{2}{*}{ Factor } & \multirow[t]{2}{*}{ Category } & \multirow{2}{*}{$\begin{array}{l}\text { No. of } \\
\text { tested }\end{array}$} & \multicolumn{6}{|c|}{ Number of seropositive samples /(cut-off) } & \multirow{2}{*}{$\begin{array}{l}\text { Prevalence } \\
\text { (\%) }\end{array}$} & \multirow[t]{2}{*}{$95 \% \mathrm{Cl}$} \\
\hline & & & 1:100 & $1: 200$ & 1:400 & $1: 800$ & $1: 1600$ & $1: 3200$ & & \\
\hline \multirow[t]{2}{*}{ Geography $^{a}$} & $\begin{array}{l}\text { North of the } \\
\text { Yellow River }\end{array}$ & 2420 & 41 & 6 & 3 & 3 & 2 & 0 & $1.69 \%$ & $1.25-2.30$ \\
\hline & $\begin{array}{l}\text { South of the } \\
\text { Yellow River }\end{array}$ & 2116 & 57 & 31 & 18 & 14 & 10 & 7 & $3.67 \%$ & $2.08-3.48$ \\
\hline \multirow[t]{4}{*}{ Season $^{b}$} & Summer & 416 & 0 & 0 & 0 & 0 & 0 & 0 & - & - \\
\hline & Spring $^{a}$ & 424 & 3 & 3 & 2 & 1 & 1 & 1 & $0.71 \%$ & $0.14-2.16$ \\
\hline & Winter & 921 & 14 & 2 & 2 & 2 & 2 & 2 & $1.52 \%$ & $0.88-2.56$ \\
\hline & Autumn ${ }^{a}$ & 3531 & 85 & 19 & 17 & 14 & 9 & 6 & $2.41 \%$ & $1.95-2.97$ \\
\hline
\end{tabular}

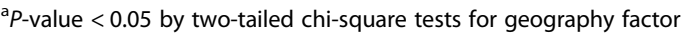

${ }^{b}$ Spring includes March, April and May. Summer includes June, July, and August. Autumn includes September, October, and November. Winter includes December, January and February

$13.49 \%, 9.34 \%$, and $35.92 \%$, respectively [1]. The seroprevalence of $T$. gondii based on screening cattle from China is $9.08 \%(1560 / 17168,1.73-46.40 \%)$ [18]. In the present study, the seroprevalence of $T$. gondii in cattle was $1.93 \%$ (102/5292), which is lower than the rest of the world and China's average infection rate. It is also lower than the seroprevalence of $T$. gondii in free-range chickens (18.86\%, 132/700) [19], ostrich (10.20\%, 20/ 197) [20], sheep $(29.33 \%, 83 / 283)$ [21], swine (13.08\%, $304 / 2325)$ [22], domestic cats $(50 \%, 21 / 42)$ [23], and large cats $(88.9 \%, 8 / 9)$ [24] in Henan Province. The maximum titer against $T$. gondii antibodies in dairy cattle was 3200 in this study. Considering the effective immune response to $T$. gondii infection in cattle, cattle with high antibody titers may be in the post-acute phase of toxoplasmosis, whereas those with low antibody titers may be in the chronic phase and may contain viable cysts of the parasite in their tissues $[1,25,26]$. However, seronegativity does not guarantee that the meat or milk from cattle will be free of $T$. gondii.

The seroprevalence of $1.93 \%$ in this survey indicates that cattle from central China are widely exposed to $T$. gondii. The route of $T$. gondii infection in cattle is probably by ingestion of $T$. gondii oocysts shed by infected felids. This finding suggests that cattle from Henan Province come into contact with T. gondii oocysts from cats or from soil, water, or feed. A single $T$. gondii felid could shed millions of oocysts after ingestion of raw meat containing $T$. gondii cysts, and the oocysts can survive in the environment for several years [27]. Furthermore, $100 \%, 10 \%$, and $71 \%$ of cats shed oocysts after primary, secondary, and tertiary infection $T$. gondii $[1,28]$. The high seroprevalence of $T$. gondii in domestic cats $(50 \%, 21 / 42)$ and wild captured large cats $(88.9 \%, 8 / 9)$ from Henan Province [23, 24] suggest that the risk of environmental contamination from felids should be given more attention.

Cattle can acquire $T$. gondii oocysts from the environment by direct contact with soil, feed, or water. The seroprevalence was highest in samples collected in autumn, suggesting that fresh grass used as cattle food may harbor $T$. gondii oocysts, and a humid environment favors the survival of oocysts in this season. The results of the present study agree with those of previous reports [29-31]. However, some studies have shown that season is not a risk factor for $T$. gondii infection [32, 33].

Henan Province is located in the downstream area of the Yellow River. LuoYang and Zhou Kou are much closer to the Yellow River than other cities, and T. gondii prevalence in the two regions is relatively higher $(P<0.05$, Fig. 1$) . T$. gondii oocysts can be transported via freshwater runoff into the ocean, thereby posing a threat to humans and other animals residing close to the river [34]. In the present study, risk factor analysis showed that geographic location is associated with $T$. gondii seroprevalence. The seroprevalence of T. gondii infection in the cattle from south of the Yellow River was higher than that of the north of the Yellow River $(P<0.05)$, which may be attributable to the mountainous geographic environment and higher temperature.

To our knowledge, neither natural cases of toxoplasmosis nor isolated strains of $T$. gondii in Chinese cattle have been reported to date. Cattle are considered poor hosts for $T$. gondii and good hosts for Neospora caninum. $N$. caninum infection in cattle has been found to be widespread in central China $[35,36]$, and this may cause reproductive losses in the cattle [37]. The dominant T. gondii genotype in China is ToxoDB\#9 [38]. Several studies have identified $T$. gondii ToxoDB\#9 in swine, domestic cats, and sheep in Henan Province [21, 23, 24, 39, 40]. However, only ToxoDB\#225 T. gondii has been identified in Chinese cattle [40]. Additional investigations on cattle toxoplasmosis are thus warranted.

\section{Conclusions}

This is the first large-scale investigation on the seroprevalence of $T$. gondii infection in cattle from central China. The rate of $T$. gondii infection in dairy cattle is 
relatively low, and this information may be integrated into the Chinese $T$. gondii epidemiology database. Additionally, geographic location appeared as a risk factor for $T$. gondii seropositivity, with prevalence of T. gondii in cattle along the Yellow River higher than those of other areas.

\section{Abbreviations}

MAT: Modified agglutination test; PCR: Polymerase chain reaction

\section{Acknowledgments}

We thank Jian Li and Zifu Zhu (Henan Agricultural University, Zhengzhou, China) for performing some of the laboratory detections.

\section{Funding}

The China Postdoctoral Science Foundation (2016 M600577) and the Program for Science and Technology Innovation Talents in Universities of Henan Province (17HASTIT038) supported this study.

\section{Availability of data and materials}

The datasets used and/or analyzed in this study are available from the corresponding author upon request.

\section{Authors' contributions}

HD and YYL performed the laboratory tests, data analysis, and wrote the manuscript; RJS, YHW, MYW, and YBJ participated in sample collection and laboratory testing; and YRY designed the study protocol, analyzed the results, and assisted in writing the manuscript. All authors read and approved the final manuscript.

\section{Ethics approval}

Verbal consent for collecting samples from the farm animals was obtained. This method is widely used in China and was approved by the ethics committee of Henan Agricultural University (China). The protocol was approved by the Beijing Association for Science and Technology (SYXK [Beijing] 2007-0023).

\section{Consent for publication}

Not applicable.

\section{Competing interests}

The authors declare that they have no competing interests. None of the authors of this report have financial or personal relationships with other people or organizations that could inappropriately influence its content.

\section{Publisher's Note}

Springer Nature remains neutral with regard to jurisdictional claims in published maps and institutional affiliations.

\section{Author details \\ ${ }^{1}$ College of Animal Science and Veterinary Medicine, Henan Agricultural University, Zhengzhou, People's Republic of China. ${ }^{2}$ Center for Animal Disease Control and Prevention of Henan Province, Zhengzhou, China.}

Received: 22 February 2018 Accepted: 25 September 2018

Published online: 19 October 2018

\section{References}

1. Dubey JP. Toxoplasmosis of animals and humans. 2nd ed. Boca Raton: CRC Press; 2010

2. Dubey JP. Isolation of Toxoplasma gondii from a naturally infected beef cow. J Parasitol. 1992;78:151-3.

3. Dubey JP, Thulliez P. Persistence of tissue cysts in edible tissues of cattle fed Toxoplasma gondii oocysts. Am J Vet Res. 1993;54:270-3.

4. Dubey JP. Toxoplasmosis- a waterborne zoonosis. Vet Parasitol. 2004;126:57-72.

5. Weiss LM, Dubey JP. Toxoplasmosis: a history of clinical observations. Int J Parasitol. 2009;39:895-901.
6. Wang ZD, Liu HH, Ma ZX, Ma HY, Li ZY, Yang ZB, Zhu XQ, Xu B, Wei F, Liu Q. Toxoplasma gondii infection in immunocompromised patients: a systematic review and meta-analysis. Front Microbiol. 2017;8:389.

7. Li JN. Analysis of toxoplasma gondii infection and risk factors in Xinxiang area. Xinxiang Med. Col., 2015; master's thesis, in Chinese.

8. Wang J, Shi DM, Cheng HC, Huo J. Serological survey of toxoplasmosis of cattle in Zhengzhou City. Chin J Vet Med. 2013;49(9):39-40 in Chinese.

9. Zhou XX, Zhou H, Ning XD, Li J, Jian FC, Zhang LX, Zhao QY, Ning CS. Seroprevalence of Toxoplasma gondii in cattle, sheep and goats in partial area of China. Chin Herb Sci. 2014;34(5):43-6 in Chinese.

10. Dubey JP, Desmonts G. Serological responses of equids fed Toxoplasma gondii oocysts. Equine Vet J. 1987;19(4):337-9.

11. Montoya JG, Liesenfeld O. Toxoplasmosis. Lancet. 2004;363(9425):1965-76.

12. Esteban-Redondo I, Innes EA. Toxoplasma gondii infection in sheep and cattle. Comp Immunol Microbiol Infect Dis. 1997;20(2):191-6.

13. Dubey JP. A review of toxoplasmosis in cattle. Vet Parasitol. 1986;22:177-202.

14. Munday BL, Corbould A. Serological responses of sheep and cattle exposed to natural Toxoplasma infection. Aust J Exp Biol Med Sci. 1979;57(2):141-5.

15. Dubey JP, Desmonts G, McDonald C, Walls KW. Serologic evaluation of cattle inoculated with Toxoplasma gondii: comparison of Sabin-Feldman dye test and other agglutination tests. Am J Vet Res. 1985;46:1085-8.

16. Qin SY, Zhou DH, Cong W, Zhang XX, Lou ZL, Yin MY, Tan QD, Zhu XQ. Seroprevalence, risk factors and genetic characterization of Toxoplasma gondii in free-range white yaks (Bos grunniens) in China. Vet Parasitol. 2015;211:300-2.

17. Jokelainen P, Tagel M, Motus K, Viltrop A, Lassen B. Toxoplasma gondii seroprevalence in dairy and beef cattle: large-scale epidemiological study in Estonia. Vet Parasitol. 2017;236:137-43.

18. Dong H, Su RJ, Lu YY, Wang MY, Liu J, Jian FC, Yang YR. Prevalence, risk factors, and genotypes of Toxoplasma gondii in food animals and humans (2000-2017) from ChinaJ. Front Microbiol. 2018;9:2108.

19. Feng YJ, Lu YY, Wang YH, Liu J, Zhang LX, Yang YR. Toxoplasma gondii and Neospora caninum in free-range chickens in Henan Province of China. Biomed Res Int. 2016;2016:8290536.

20. Feng YJ, Lu YY, Wang YH, Zhang LX, Yang YR. Toxoplasma gondii and Neospora caninum in farm-reared ostriches (Struthio camelus) in China. BMC Vet Res. 2017;13(1):301.

21. Yang Y, Feng Y, Yao Q, Wang Y, Lu Y, Liang H, Zhu X, Zhang L. Seroprevalence, isolation, genotyping, and pathogenicity of Toxoplasma gondii strains from sheep in China. Front Microbiol. 2017;8:136.

22. Wang HY, Ren QE, Jian FC, Zhou Y, Zhang LX, Ning CS. Investigation on the swine Toxoplasma gondii infection in some districts of Henan province and the inoculation experiment in mice infected with isolates from pigs. Chin J Zoonoses. 2008;24(10):930-2 in Chinese.

23. Yang $Y$, Ying $Y$, Verma SK, Cassinelli AB, Kwok OC, Liang H, Pradhan AK, Zhu XQSC, Dubey JP. Isolation and genetic characterization of viable Toxoplasma gondii from tissues and feces of cats from the central region of China. Vet Parasitol. 2015;211:283-8.

24. Yang YR, Feng YJ, Lu YY, Dong H, Li TY, Jiang YB, Zhu XQ, Zhang LX. Antibody detection, isolation, genotyping, and virulence of Toxoplasma gondii in captive felids from China. Front Microbiol. 2017;8:1414.

25. Carmo ELD, Morais RDAPB, Lima MS, Moraes CCG, Albuquerque GR, Silva AVD, Povoa MM. Anti-Toxoplasma gondii antibodies in beef cattle slaughtered in the metropolitan region of Belem. Brazilian Amazon Rev Bras Parasitol Vet. 2017;26(2):226-30.

26. Opsteegh M, Teunis P, Zuchner L, Koets A, Langelaar M, van der Giessen J. Low predictive value of seroprevalence of Toxoplasma gondii in cattle for detection of parasite DNA. Int J Parasitol. 2011;41(3-4):343-54.

27. Afonso E, Germain E, Poulle ML, Ruette S, Devillard S, Say L, Villena I, Aubert $D$, Gilot-Fromont E. Environmental determinants of spatial and temporal variations in the transmission of Toxoplasma gondii in its definitive hosts. Int J Parasitol Parasites Wildl. 2013;2:278-85.

28. Zulpo DL, Sammi AS, Dantos JRD, Sasse JP, Martins TA, Minutti AF, Cardim ST, Barros LDD, Navarro IT, Garcia JL. Toxoplasma gondii: a study of oocyst re-shedding in domestic cats. Vet Parasitol. 2018;249:17-20.

29. Dubey JP. Toxoplasma gondii oocyst survival under defined temperatures. J Parasitol. 1998:84:862-5.

30. Boughattas S, Behnke J, Sharma A, Abu-Madi M. Seroprevalence of toxoplasma gondii infection in feral cats in Qatar. BMC Vet Res. 2017;13(1):26.

31. Liu XC, He Y, Han DG, Zhang ZC, Li K, Wang S, Xu LX, Yan RF, Li XR. Detection of Toxoplasma gondii in chicken and soil of chicken farms in Nanjing region. China Infect Dis Poverty. 2017;6(1):62. 
32. Zhang XX, Shi W, Zhang NZ, Shi K, Li JM, Xu P, Zhao Q, Prevalence DR. Genetic characterization of Toxoplasma gondii in donkeys in northeastern China. Infect Genet Evol. 2017;54:455-7.

33. Elfahal AM, Elhassan AM, Hussien MO, Enan KA, Musa AB, El Hussein AM. Seroprevalence of Toxoplasma gondii in dairy cattle with reproductive problems in Sudan. ISRN Vet Sci. 2013;2013:895165.

34. Fayer R, Dubey JP, Lindsay DS. Zoonotic protozoa: from land to sea. Trends Parasitol. 2004;20:531-6.

35. Yang YR, Zhang QF, Kong YG, Ying YQ, Kwok OCH, Liang H, Dubey JP. Low prevalence of Neospora caninum and Toxoplasma gondii antibodies in dogs in Jilin, Henan and Anhui provinces of the People's Republic of China. BMC Vet Res. 2014;10:295.

36. Qian W, Wang T, Yan W, Zhang M, Han L, Xue R, Song S, Lv C. Seroprevalence and first multilocus microsatellite genotyping of Neospora caninum in dairy cattle in Henan. central China Vet parasitol. 2017;244:81-4.

37. Dubey JP, Hemphill A, Calero-Bernal R, Schares G. Neosporosis in animals. Boca Raton: CRC Press; 2017

38. Pan M, Lyu C, Zhao J, Shen B. Sixty years (1957-2017) of research on toxoplasmosis in China-an overview. Front Microbiol. 2017;8:1825

39. Wang H, Zhang L, Ren Q, Yu F, Yang Y. Diagnosis of swine toxoplasmosis by PCR and genotyping of Toxoplasma gondii from pigs in Henan. Central China BMC Vet Res. 2017:13:152.

40. Qian WF, Yan WC, Wang TQ, Shao XD, Zhai K, Han LF, Lv CC. Genetic characterization of Toxoplasma gondii from domestic animals in Central China. Trop Biomed. 2015;32:540-4.

Ready to submit your research? Choose BMC and benefit from:

- fast, convenient online submission

- thorough peer review by experienced researchers in your field

- rapid publication on acceptance

- support for research data, including large and complex data types

- gold Open Access which fosters wider collaboration and increased citations

- maximum visibility for your research: over $100 \mathrm{M}$ website views per year

At $\mathrm{BMC}$, research is always in progress.

Learn more biomedcentral.com/submissions 